\title{
"A POLÍCIA MANDA, MAS A POLÍCIA MANDA \\ PARALELO COM AS PRESAS": O FUNCIONAMENTO \\ DA INSTITUIÇÃO PENAL ENQUANTO APARELHO \\ REPRESSOR DE ESTADO
}

\section{“THE POLICE GIVES ORDERS, BUT IN A PARALLEL WAY WITH THE PRISONERS”: THE FUNCTION OF THE PRISON AS A REPRESSIVE STATE APPARATUS}

\author{
Luciana Iost Vinhas \\ Universidade Federal do Rio Grande, Instituto de Artes e Letras, Rio Grande, RS,
} Brasil

\begin{abstract}
Resumo: $\mathrm{O}$ presente trabalho objetiva refletir sobre o funcionamento da instituição penal no seio da formação social contemporânea, sendo a instituição compreendida enquanto parte do Aparelho Repressivo de Estado. Dessa forma, toma-se como base os pressupostos de Louis Althusser, os quais foram objeto de uma releitura por Michel Pêcheux. É, portanto, na Análise do Discurso francesa que o estudo se ancora, sendo realizada uma comparação entre elementos presentes em um documento do Conselho Nacional de Justiça (a Cartilha da Mulher Encarcerada) e a fala de uma apenada da Penitenciária Feminina Madre Pelletier, entrevistada em abril de 2013. Com a análise, percebe-se que, apesar da haver, por parte da superestrutura, uma tentativa de transformar os sujeitos em corpos individualizados, objetos de controle do Estado, há, ainda, no interior da prisão, espaço para resistência, pois as apenadas conseguem encontrar brechas para instalar um modo de funcionamento próprio ao interior das galerias, inacessível ao Aparelho.
\end{abstract}

Palavras-chave: Aparelho Repressivo de Estado; discurso; resistência; prisão.

Abstract: The present study aims to reflect on how the penal institution works in the current social formation, assuming that this institution is part of the Repressive State Apparatus. Thereby, the basis of this work is Louis Althusser's philosophical thought, which is object of Michel Pêcheux's assumptions. This study is anchored in French Discourse Analysis, and a comparison between elements from a document published by the National Council of Justice (the Book of the Incarcerated Woman) and the speech of an inmate from Madre Pelletier Woman's Prison, interviewed in April 2013, is made. With the analysis, it is understood that, in spite of the superstructure's attempts of transforming the subjects in individualized bodies, objects of the control of the State, there is, still, the possibility of resisting in the interior of the prison, and the inmates can find spaces to install a singular way of functioning in the interior of the galleries, inaccessible to the Apparatus.

Keywords: Repressive State Apparatus; Discourse; Resistance; Prison. 


\section{Introdução}

A compreensão do funcionamento da instituição penal no seio da formação social atual demanda um movimento de retorno às reflexôes de Louis Althusser sobre os Aparelhos de Estado. Sua obra é basilar para a constituição da Análise do Discurso (AD), posto que Michel Pêcheux, responsável pelo surgimento e consolidação desta região instável das ciências humanas, calcou-se nos textos althusserianos quando começou a desenvolver sua busca por uma filosofia da linguagem de cunho marxista. O cerne desta "aventura teórica" está na articulação entre o Materialismo HistóricoDialético (enquanto ciência e filosofia), a Linguística e a Teoria do Discurso, três regiōes atravessadas e articuladas por uma teoria da subjetividade (de natureza psicanalítica), conforme Pêcheux e Fuchs (1997).

Constitutivamente heterogênea, a Análise do Discurso traz à tona questóes concernentes à materialidade significante, a qual inexiste fora de uma relação sócio-histórico-ideológica. Tomando a língua como materialidade, pode-se dizer que ela possui um funcionamento discursivo, através do qual se materializa o processo de interpelação ideológica. Esse processo somente é possível pela organização da estrutura social em aparelhos que regulam as práticas dos sujeitos via ideologia e repressão.

É com base na Análise do Discurso que se desenvolverá o presente debate, tomando como foco o funcionamento da prisão através da descrição e da interpretação de diferentes materialidades significantes. Desse modo, tendo como sustentação teórica o entendimento de Althusser sobre os Aparelhos de Estado, e, também, a interpretação de Pêcheux desses elementos, o objetivo do estudo é abordar a relação entre a superestrutura jurídico-político-ideológica, representada aqui pelo Aparelho Repressivo de Estado Prisional, e os sujeitos inseridos nesse aparelho. Para tanto, será feita a análise de elementos presentes em um documento do Conselho Nacional de Justiça, a saber, a Cartilha da Mulher Encarcerada, a qual será confrontada com a análise da fala de uma apenada da Penitenciária Feminina Madre Pelletier, entrevistada em abril de $2013^{1}$.

\footnotetext{
${ }^{1}$ A fala da apenada está presente no banco de dados do projeto "De sujeito a objeto: o corpo no discurso de mulheres presidiárias", vinculado à linha de pesquisa "Análises textuais e discursivas", do Programa de Pós-Graduação em Letras, da Universidade Federal do Rio Grande do Sul.
} 


\section{Delimitando o tema: Foucault, Ansart e Haroche}

Como foi mencionado, esta discussão está ancorada na Análise do Discurso pecheuxtiana, para a qual os pressupostos althusserianos são fundamentais. Apesar disso, é importante estabelecer uma reflexão vinculada a saberes de outros pensadores que versam sobre a instituição penal. São eles: Michel Foucault, Pierre Ansart e Claudine Haroche.

Foucault (2005; 2006) diz que, na história da repressão, há dois momentos: a punição e a vigilância. Isso se dá, principalmente, porque vigiar passa a ser considerado mais eficaz e rentável do que punir (FOUCAULT, 2006). Ao se passar da punição para a vigilância, foi operado um deslocamento do objeto da repressáo. Primeiramente, o objeto da repressão era o corpo, através dos suplícios; mais tarde, o objeto passou a ser a alma, ocorrendo a perda de um bem ou de um direito. Em função de a punição se dar na alma, há, na prisão, a vigilância agindo sobre corpos dóceis: "é dócil um corpo que pode ser submetido, que pode ser utilizado, que pode ser transformado e aperfeiçoado" (FOUCAULT, 2005, p. 118).

Essa expressão entra em circulação juntamente com a ideia de que a disciplina seria o mecanismo de controle dos presos. A disciplina é considerada o elemento principal para a transformaçáo da punição para a vigilância, pois é a base para o entendimento do controle dos comportamentos individuais, sendo a modalidade através da qual se vigiam e se dominam os corpos. Para o autor, ela concerne aos métodos "que permitem o controle minucioso das operaçóes do corpo, que realizam a sujeiçấo constante de suas forças e lhes impóem uma relação de docilidade-utilidade" (FOUCAULT, 2005, p. 118).

Ainda é importante mencionar que a prisão é uma instituição de arquitetura panóptica, e, em função disso, também é chamada por Foucault (2005) de instituiçâo de sequestro. Tais instituiçôes visam a controlar o tempo dos indivíduos, extraindo dele a sua totalidade, e também os seus corpos. $\mathrm{O}$ objetivo é fixar os indivíduos a um aparelho de normatizaçáo dos homens (aparelhos de produção, formação, reformação ou correção de produtores).

Além de Foucault (2005), alguns elementos delineados pelo filósofo e sociólogo Pierre Ansart (2005) acerca das humilhaçôes políticas enquanto uma das experiências da impotência são relevados. Para ele, a humilhação é entendida como "importante elemento instituinte e estruturador das relaçóes de poder no mundo moderno" (MARSON; NAXARA, 2005, p. 10). As humilhaçóes políticas seriam uma das experiências da impotência, posto que se trata de situaçóes nas quais não existe a possibilidade de o agente que sofre a influência da humilhação revoltar-se contra o seu autor. 
Ansart (2005) elenca dois níveis de análise para a humilhação. O primeiro deles diz respeito à situaçáo em que se opóe um ator (individual ou coletivo) que exerce uma influência, o qual não tem ação frente à situação na qual foi colocado; o segundo nível refere-se a um sofrimento, pois se trata de um desrespeito, de uma ferida no amor próprio, de uma desvalorização da autoimagem. $\mathrm{O}$ autor traz, ainda, as três formas de humilhação observadas na história recente, a saber, as humilhações radicalmente destrutivas, as humilhaçôes superadas e as humilhaçóes instrumentalizadas.

É importante mencionar aqui algo retratado acerca da humilhaçáo destrutiva, visto que parece coadunar-se com o pensamento de Foucault quanto ao exercício do poder. A humilhação destrutiva dá-se, prioritariamente, através da violência simbólica, isto é, não há humilhação no corpo, e acaba por construir a docilidade em resposta a estímulos do ator que promove a humilhação. Em função disso, a docilidade é compreendida por Ansart (2005) como uma mecanicidade dos corpos. Isso indica a simples repetição de padróes comportamentais pelos sujeitos em situaçáo de humilhação, destituindo-os de uma posiçáo de resistência frente ao exercício do poder. Conforme Ansart (2005, p. 18):

\begin{abstract}
A criação de situaçóes de humilhação, a prática da humilhação é, portanto, uma arma do poder instalado, uma arma estratégica que visa à perfeita docilidade do cidadão. A história do movimento que conduziu à ascensão do regime totalitário nos mostra que a prática da humilhação generalizada, combinada às ameaças policiais, se impôs, conseguindo em particular aniquilar a pessoa, negá-la, para que suas próprias reaçôes naturais fossem destruídas. [...] $\mathrm{O}$ acúmulo de humilhaçôes chega a destruir a pessoa e a suprimir a questáo do sentido de sua existência.
\end{abstract}

Retratando um conto de Alexander Soljenitsin, Ansart (2005, p. 18) afirma que "existe um estado limite para a humilhação, um poder inerente às práticas humilhantes que podem ir além do projeto de calar a expressão da resistência e podem reduzir o cidadáo a uma espécie de funcionamento mecânico que o destitui de identidade". Nesse ponto, Ansart coloca a transformação do cidadão em uma ausência, pois não existe a possibilidade de resistência no caso dos sujeitos humilhados: eles, simplesmente, deixam de se identificar.

Dessa forma, a humilhação passa a ser um tema importante para pensar-se sobre a política constitutiva da instituição penal, pois seria impossibilitada a resistência dos sujeitos pela impotência instaurada através dela. Seguindo nessa esteira, Claudine Haroche possui reflexôes referentes 
à relação entre o indivíduo e o Estado, bem como ao seu resultado, ou seja, à condição de humilhação. Haroche (1992, p. 21) assume que "o poder, o Estado, o direito, coagem o sujeito, insinuam-se nele de forma discreta; todos tornam-se claros processos que derivam de uma técnica particular de poder que Foucault, em um dos últimos textos, designa como sendo de 'governo pela individualização'”.

No entendimento da autora, a individualização, alcançada através da "exigência de clareza, de desambiguização, de determinação, de perfeita legibilidade" (HAROCHE, 1992, p. 22) passa a ser o processo de alienação da contemporaneidade. Trata-se de um mecanismo coercitivo, imposto ao indivíduo pelo Estado, o qual impossibilita a resistência e a revolta. A individualização leva à humilhação, ou melhor, esse isolamento imposto nas sociedades democráticas conduz à repetibilidade e à intensidade da humilhação (HAROCHE, 2005). Existe, portanto, uma individualização ocorrida através da gramática e do discurso, levando a uma responsabilização do sujeito pelo que diz (o sujeito de direito). Esse sujeito da ordem jurídica responde por si, sendo, portanto, transformado pelo Estado em um homem uniforme e mensurável, ou seja, individualizado.

Tal é a forma-sujeito de direito da contemporaneidade, segundo a autora. A individualização incitada pelo Estado ao sujeito de direito da sociedade contemporânea acarreta na humilhação e na dessubjetivização do sujeito, na sua corporeificação, visto que "a humilhação reside no fato de se estar reduzido ao eu e, consequentemente, ao corpo" (HAROCHE, 2005, p. 43). Ser sujeito é ser somente corpo uno e mensurável, capaz de ser humilhado, mas de não ter consciência de sua humilhação (ele somente consegue senti-la).

Conforme a autora, a passividade na qual o indivíduo é alocado conduz à humilhação, à impotência, não encontrando mais sentido na sociedade, tampouco em si mesmo. Sendo assim, a sociedade contemporânea "desvaloriza os indivíduos, sua singularidade, sua criatividade e imaginação, a pessoa em cada um; ela entrava e destrói a subjetividade na medida que interdita toda capacidade psíquica que demande um tempo necessário à reflexão, à relação consigo mesmo, à consciência de si” (HAROCHE, 2005, p. 32-33). 


\section{$2 \mathrm{O}$ processo de interpelação ideológica e a prisão: Althusser e Pêcheux}

Louis Althusser, ao abordar os Aparelhos Ideológicos de Estado, possibilita a Michel Pêcheux, posteriormente, pensar sobre esses Aparelhos enquanto formaçóes ideológicas, pois cada formação ideológica representa uma das instituiçôes presentes no edifício da estrutura social, e cada instituição é compreendida como um Aparelho Ideológico de Estado (PÊCHEUX, 2009). A formação discursiva, outra noção pecheuxtiana (resgatada de Foucault), materializa o político no discursivo, ou seja, é através delas que se percebem as contradiçôes presentes-ausentes na materialidade sob análise. A formaçáo discursiva revela a impossibilidade de o sentido ser somente um e de o discurso constituir-se em condições de produção homogêneas.

Para Althusser, a estrutura jurídico-político-ideológica é organizada em Aparelhos de Estado - vários Aparelhos Ideológicos e um Aparelho Repressivo - os quais regulam as relaçóes de poder da sociedade e constituem a superestrutura. Ela diz respeito à instância tanto jurídico-política (o Direito e o Estado, representados pelo Aparelho Repressor) quanto ideológica (as distintas ideologias: religiosa, moral, jurídico, política, etc., as quais representam os Aparelhos Ideológicos). Além da superestrutura, também existe a infraestrutura, onde estão os sujeitos aparentemente livres, que concerne à base econômica da sociedade (unidade de forças produtivas e relaçóes de produção).

Enquanto o Aparelho Repressivo de Estado (ARE) é, conforme Althusser (2003), o governo, a administraçáo, o exército, a polícia, os tribunais e as prisóes, os Aparelhos Ideológicos de Estado (AIE) aludiriam a "um certo número de realidades que apresentam-se ao observador imediato sob a forma de instituiçóes distintas e especializadas" (ALTHUSSER, 2003, p. 68). Repressivo é o aparelho de estado que funciona através da violência, sendo que a repressão administrativa pode revestir-se de formas não físicas. O ARE e os AIE são instituiçóes, públicas e privadas, responsáveis por regular os sujeitos, e, também, por transformar os indivíduos em sujeitos no processo de interpelação ideológica.

Apesar de os dois tipos de Aparelho de Estado não serem totalmente ideológicos e privados, de um lado, tampouco repressor e público, de outro, a caracterização deles se dá, respectivamente, como AIE e ARE, de forma predominante. Além disso, o que caracteriza o Aparelho Ideológico de Estado seria o seu mecanismo de controle, a saber, ideológico, em sua maior parte. Já o Aparelho Repressivo de Estado não só opera através da ideologia, mas também através da violência e tem como modo principal de 
funcionamento a repressão, inclusive a física, o que não significa dizer que existe aparelho puramente repressivo. A penitenciária seria um ARE, mas que não funciona somente através da violência física.

O objetivo, tanto nos AIE como no ARE, é manter a reprodução de "valores", seja por mecanismos ideológicos ou por mecanismos repressivos. Conforme Althusser (2008, p. 185, grifo do autor), "a superestrutura mantém com a infra-estrutura a relação específica de reproduzir as condiçóes de funcionamento desta última"

Quanto ao processo de interpelaçáo ideológica, vale a pena atentar para o que Pêcheux (2009) menciona quando aborda o efeito Münchhausen (o efeito fantástico pelo qual o indivíduo é interpelado em sujeito). Para o autor, a interpelação torna tangível o vínculo superestrutural "entre o aparelho repressivo de Estado (o aparelho jurídico-político que distribuiverifica-controla 'as identidades') e os aparelhos ideológicos de Estado, portanto: o vínculo entre o sujeito de direito; seus iguais) e o sujeito ideológico (aquele que diz ao falar de si mesmo: 'Sou eu!')" (PÊCHEUX, 2009 , p. 140, grifos do autor). O sujeito de direito e o sujeito ideológico são vinculados pelo processo de interpelação, responsável pela evidência do sujeito como único, insubstituível e idêntico a si mesmo e pela evidência do sentido.

É importante frisar que esse vínculo superestrutural é determinado pela infraestrutura, a base econômica, de modo que as relaçóes entre os Aparelhos de Estado no processo de interpelaçáo dependem do nível infraestrutural, existindo a chance de acontecer um retorno da infraestrutura para a superestrutura. Tal possibilidade ocasionaria uma transformação nas relaçôes de produção e, por conseguinte, no processo de interpelação ideológica.

Pêcheux (2009) também menciona o recrutamento exercido pela ideologia, chamando todos os indivíduos a tornarem-se sujeitos. $\mathrm{O}$ importante é compreender de que modo acontece esse recrutamento, isto é, "de que modo todos os indivíduos recebem como evidente o sentido do que ouvem ou dizem, lêem ou escrevem” (PÊCHEUX, 2009, p. 144, grifos do autor).

Para tanto, aquilo que pode e deve ser dito, aquilo que pode e deve ser reproduzido como evidente, é um efeito do processo de interpelação ideológica. Nesse processo, as formaçóes ideológicas exercem um papel fundamental, pois representam as instituiçóes que controlam os sentidos, mantendo a regularidade do processo discursivo e apaziguando os efeitos dispersivos desse processo. As formaçôes ideológicas buscam não colocar as 
formaçôes discursivas em confronto, pois, a partir desse movimento, pode emergir a polissemia no eixo da formulação, o que ocasiona o reordenamento das relaçôes de dominação dentro da formação ideológica.

O funcionamento do processo de interpelação ideológica possui suas idiossincrasias no que concerne ao sujeito em relação com a lei. Por um lado, tem-se a atuação do Aparelho Repressivo de Estado, o qual precisa garantir que os sujeitos de direito cumpram a lei; por outro lado, há, entre os Aparelhos Ideológicos de Estado, o Aparelho Jurídico. Ao Aparelho Jurídico corresponde a formação ideológica jurídica, a qual é constitutivamente contraditória, pois nela estão presentes, pelo menos, duas formaçóes discursivas, as quais dizem respeito aos saberes da Justiça e aos saberes da Criminalidade. Sendo assim, é possível afirmar que o sujeito preso é aquele que foi capturado pelo Estado (ARE) e teve seus direitos suspensos na sociedade de direito através da punição via privação de liberdade, posto que se identifica com a Formaçáo Discursiva da Criminalidade e reproduziu essa identificação através de um crime. Foi essa prática que possibilitou ao Estado torná-lo objeto de julgamento e de punição. A falha acontece na instância ideológica, visto que o ARE não admite contradição.

Quando na prisão, o sujeito, por estar sob as determinações do ARE, deve lhes obedecer. Contudo, por a prisão também ser atravessada pela instância ideológica, haveria a possibilidade de subversão, da não identificação do sujeito com os saberes que lhe interpelam de forma coercitiva (ao contrário do que acontecia quando o sujeito encontrava-se em liberdade, como sujeito de direito). A possibilidade de subversão dos sentidos é, em virtude da aparente fixidez da relação de dominância entre as formaçôes discursivas, bastante reduzida por se manifestar através da linguagem jurídica, compreendida como homogênea, vinculada ao discurso jurídico (HAROCHE, 1992; 2005), no qual todos os sentidos são evidentes e a linguagem não é passível de outra interpretação além daquela da lei. Entretanto, para Pêcheux, ainda assim seria possível se rebelar e ousar pensar por si mesmo, pois os sujeitos são constituídos na e pela linguagem e, em função disso, a falha é possível, mesmo em situaçôes de extrema coerção.

\section{O ARE e o sujeito em confronto}

Compreendendo que a ideologia tem uma existência material (ALTHUSSER, 2008), será feita aqui a análise de duas materialidades, a fim de confrontar os saberes colocados em circulação a partir delas. De um lado, falaremos sobre a primeira edição da Cartilha da Mulher Encarcerada 
(CNJ, 2011), publicada pelo Conselho Nacional de Justiça, e cuja primeira ediçấo data de 2011; de outro lado, será trazida para discussão uma fala de uma apenada da Penitenciária Feminina Madre Pelletier, entrevistada em 2013.

A cartilha referida, documento que coloca em circulação a lei (vinculada ao Aparelho Repressivo de Estado), bem como discursos atrelados à formação discursiva Jurídica (vinculados ao Aparelho Ideológico de Estado Jurídico), representa a superestrutura jurídico-político-ideológica. Em contrapartida, a fala da apenada entrevistada, ao atualizar os saberes das formaçóes discursivas (FD Jurídica e FD da Criminalidade), representa os sujeitos presos.

Quanto à primeira materialidade referida, composta por elementos verbais e não verbais distribuídos em um texto escrito, pode-se dizer que ela apresenta os direitos e os deveres das mulheres presas, dentre outras informaçóes referentes à vida na prisão. A capa mostra uma mulher que, subentende-se, está presa. Os elementos visuais que chamam a atenção nessa suposta presa são a expressão facial, pois não parece estar triste, tampouco feliz. Sua pele é morena e o cabelo está preso; o olhar está direcionado para a direita, como se estivesse olhando para o futuro, longe, com esperanças, e os sentidos que emergem parecem apontar para o entendimento de que o futuro lhe reserva algo melhor (se ela cumprir com as informaçóes presentes na cartilha) ${ }^{2}$.

Interessante observar a expressão que segue à identificação do Conselho Nacional de Justiça como responsável pela autoria da cartilha. Ao dizer "O Brasil faz a justiça", na capa, ao lado da imagem de uma mulher presa, a relação que pode ser estabelecida é a de que a mulher que está presa (a leitora potencial do documento), de posse da cartilha está onde ela deveria estar, pois a justiça foi feita e ela deve se conformar com a sua atual conjuntura (deve significar a partir da formaçáo discursiva da Justiça).

O documento elaborado pelo Conselho Nacional de Justiça representa o discurso da superestrutura, ou seja, no aparelho ideológico prisional, o discurso dominante é aquele da superestrutura jurídico-político-ideológica (repressora), e a instância que organiza esse discurso é o Conselho Nacional de Justiça. Sendo assim, ao observar os sentidos que entram em circulaçáo a partir da cartilha, podemos identificar aqueles que podem e devem circular na prisão, ou seja, com quais discursos as presas podem e devem se identificar.

2 O documento pode ser observado no site <http://www.cnj.jus.br/images/programas/ comecar-de-novo/publicacoes/cartilha_da_mulher_presa_1_portugues_4.pdf>. Acesso em: 19 jun. 2014. 
$\mathrm{Na}$ apresentação do documento, é mencionado que nele constam "informaçóes claras e diretas sobre garantias constitucionais, prerrogativas legais e administrativas" (CNJ, 2001, p. 9), tratando-se de uma ferramenta para a ressocialização da mulher presa. Essa afirmação não se coaduna com o pensamento foucaultiano. $\mathrm{O}$ autor menciona que a instituição penal age como uma escola da delinquência: a prisão não transforma os indivíduos em gente honesta, mas, sim, fabrica novos delinquentes ou afunda-os ainda mais na criminalidade (FOUCAULT, 2006). Chega-se a isso através da extração da totalidade do tempo e do controle dos corpos.

Na primeira parte da cartilha, distintas formas de se fazer referência às mulheres são utilizadas. Três delas, a saber, "mulheres presas", "mulheres encarceradas" e "aquelas que se encontram privadas de liberdade" aparecem indistintamente. Ser presa, estar no cárcere, é não ter liberdade, ou seja, ter os direitos suspensos, o que náo acontece com o sujeito de direito (que está na sociedade). Por isso, há uma legislação própria àqueles sujeitos que se encontram enclausurados, pois eles deixaram de ter garantido o direito de ser sujeito conforme a forma-sujeito da contemporaneidade. Eles devem, portanto, identificar-se com esse conjunto de leis que rege os seus comportamentos, pois se transformaram em sujeitos vigiados, disciplinados. Ao não se ter liberdade, não se é sujeito; assim, é necessário obedecer à lei para sobreviver.

Depois da apresentação, são referidos os direitos das mulheres presas. Todo o texto da cartilha apresenta uma mesma forma de organização. São frases simples, distribuídas de forma bastante didática (como uma cartilha propriamente dita) e, inclusive, com cores e desenhos que identificam os tópicos abordados em alguns parágrafos considerados mais importantes. Além disso, em parágrafos com informaçôes essenciais, os dizeres aparecem em vermelho e em caixa alta.

Na página 11 da cartilha (CNJ, 2011), há três desenhos que antecedem os parágrafos principais, os quais tratam dos seguintes temas: a Constituição Federal, a possibilidade de denunciar abusos na prisáo e a liberdade religiosa na prisão. Para cada um deles, há um desenho, respectivamente: o símbolo da justiça (com uma representação gráfica simples); a imagem de um rosto com a boca aberta, como se estivesse reclamando, em vermelho; e uma mulher com as mãos em forma de oração, com um livro e uma planta ao seu lado.

Passamos à discussão do primeiro parágrafo da página referida. Nele, afirma-se: "a Constituição Federal, lei maior de nosso país, traz no art. $5^{\circ}$ os direitos e garantias fundamentais de todos os cidadãos e cidadâs. 
Embora tenha sido presa, você é uma cidadã e como tal deve ser tratada" (CNJ, 2011, p. 11). Parece que a necessidade de isso ser dito às presas está ligada ao pré-construído de que presa não é cidadã. Sendo assim, o trabalho da superestrutura, ao disponibilizar as cartilhas para as presas, está em desvinculá-las de discursos com os quais se identificavam antes de entrar na prisão. Eles dizem respeito à representaçáo de presa que circula na sociedade enquanto um pré-construído.

Outro enunciado que deve ser discutido é "você tem o direito de ser chamada pelo nome" (CNJ, 2011, p. 12). Ele está presente na segunda página em que são listados os direitos das presas. $\mathrm{O}$ enunciado relaciona-se ao que é mencionado por Foucault sobre as prisóes. Nesses lugares, a identificação dos presos era feita por números; desse modo, ser chamado pelo nome, mais uma vez, subverte aquilo que se espera da instituição prisional, pois ela é contrária ao pré-construído que a determina: o sujeito preso não é chamado pelo nome. O pré-construído, entấo, deve ser refutado; no entanto, ele é justamente o saber vinculado ao discurso dominante.

Quatro sequências discursivas que tratam do mesmo tema chamam a atenção no texto da cartilha (CNJ, 2011, p. 11): (i) "Você tem direito de não sofrer violência física ou moral, de não ser submetida à tortura nem a tratamento desumano ou cruel"; (ii) "É proibida qualquer forma de coação física (tapas, chutes, socos), moral ou psíquica (palavróes, provocaçóes, ameaças, insultos, humilhações, etc.)"; (iii) "Nenhuma autoridade ou servidor penitenciário pode usar de violência física ou psicológica"; e (iv) "Se esse tipo de violência acontecer, denuncie! Fale com o defensor público, promotor de justiça ou juiz que visita a unidade prisional. Sua família também pode fazer a denúncia!". Essas informaçôes aparecem na primeira página dedicada aos direitos das mulheres presas, o que revela a importância de ser assegurado o direto a não violência.

No que concerne a essas afirmaçóes, uma primeira pergunta emerge: quem seria o agente das informaçôes repetidas? Na terceira sequência são mencionados dois possíveis agentes dessas violências contra as presas: alguma autoridade ou servidor penitenciário. Isso significa que já seria recorrente esse tipo de coação na instituição prisional. Um aspecto interessante que cerca essas informaçôes diz respeito à repetição.

Retomando o que diz Althusser (2003; 2008) sobre a prisão, chamamos a atenção para a sua classificação enquanto Aparelho Repressivo de Estado, ou seja, trata-se de um aparelho que funciona, prioritariamente, através da violência. É com base nisso que a cartilha busca impedir a violência na prisão; por outro lado, parece que ela acontece por outras vias, 
ou seja, através da "alma" e não do corpo, a qual é mencionada por Foucault. Só é permitido à instituição penal agir sobre as almas dos indivíduos e, caso aconteça alguma violência sobre os seus corpos, isso deve ser denunciado.

A fim de confrontar o discurso do ARE ao discurso de sujeitos presos, é trazida para discussão a fala de uma apenada. Quando da realização da entrevista, ela estava presa há seis anos e deveria permanecer na penitenciária por mais sete anos. Foi presa por assalto a banco e por homicídio, sendo que trocou tiros com a polícia.

Dentre as várias perguntas feitas à apenada em uma entrevista de 29 minutos, uma delas traz elementos importantes sobre a relação entre o Aparelho Repressor de Estado e os sujeitos presos. Já no final da entrevista, foi questionado se a apenada gostaria de relatar alguma outra coisa a respeito da vida na penitenciária. Ela começou falando sobre a dificuldade de convivência com as outras apenadas, principalmente com as provisórias, e, em seguida, sem que fosse feita nenhuma pergunta específica sobre o assunto, abordou a relaçáo entre o poder da polícia e o poder de dentro das galerias, como pode ser observado na sequência discursiva recortada da fala da apenada.

[SD] entre as presas... ou discussão ou... alguém vem apaziguá... ou elas brigam mesmo... e pronto... termina ali... a não sê qui né... que uma mais escandalosa desça correndo a escada e chame a polícia né... mas geralmente é resolvido entre a genti mesmo... internamente dentro da galeria... é assim... o sistema todo é assim... né... a polícia manda... mas a polícia manda... paralelo... com as presas... eles mandam... mas a genti... as presa também mandam... é... embora eles não... eles não assumam isso né... eles sabem que tem... toda cadeia tem todas as cadeia têm... tem o controle pra fora do portão ih o controle pra dentro do portáo né... e as presas têm que íh no ritmo... que a cadeia é... pra corrê tudo bem... por exemplo eu não me envolvo com nada... pra mim tá tudo bem... agora chega uma uma que já não vai aceitá é aí as regra da cadeia toda cadeia tem regra e cada galeria tem a sua regra também... então... aí já fica difícil né... mas tem um controle paralelo sim... meio das presa e meio deles embora eles nunca vão assumi isso né eles acham que têm o controle total da cadeia isso é mentira

A instituição penal parece funcionar de modo independente com relaçáo ao resto das instituiçóes que constituem a superestrutura de determinada formação social. Ela recebe sujeitos que devem sofrer uma punição através da privação da liberdade e, após um determinado período, libera esses sujeitos de volta à dita sociedade. O que acontece dentro da prisão é regulado pelo Aparelho Repressor de Estado (o próprio Estado, suas leis e suas coerçôes); contudo, no interior do presídio, dentro das 
galerias, existem outras leis e outras coerções. É como se, na sociedade, existisse uma instituiçáo cujo funcionamento depende da criminalidade, ou seja, da não-identificação de sujeitos com a forma-sujeito de direito, e, dentro dessa instituição, esses mesmos sujeitos obedecessem às regras do $\mathrm{ARE}$, mas, além disso, fizessem as suas próprias regras, corroborando a nãoidentificação à forma-sujeito de direito. $\mathrm{O}$ fato de não chamarem as agentes penitenciárias para resolverem os conflitos internos revela que uma outra lei rege o funcionamento dentro das galerias.

A apenada não foi questionada sobre o motivo de não chamarem as agentes penitenciárias quando acontecem as discussôes no interior das galerias; no entanto, pode-se supor que há o receio de que as agentes possam estabelecer uma punição em função do mau comportamento de algumas apenadas. Nesse sentido, a fim de escapar de uma punição dentro da prisão, existe um consenso estabelecido entre elas de que não devem interpelar o ARE no caso de conflitos internos. Esse consenso seria uma forma de resistência dentro da prisão, isto é, trata-se de uma forma de não obedecer ao Aparelho a fim de escapar do castigo. Indica que, apesar das brigas entre as apenadas, há uma tentativa de autoproteçáo, revelando o funcionamento de um regulamento interno; contudo, apesar de estarem aprisionadas, adquirem, por meio desse consenso velado, o direito de resistir a mais uma puniçáo. Conforme a apenada, tudo é resolvido internamente no próprio momento em que ocorre a briga, e esse ritual se mantém durante certo tempo, pois, segundo ela, "sempre foi... sempre foi assim".

Além disso, é possível estabelecer um diálogo com o pensamento de Ansart. Há, da parte das presas, por meio desse consenso, a tomada de medidas para evitar a humilhação, enquanto elemento que estrutura as relaçôes de poder. Ao chamarem as agentes penitenciárias para resolverem os conflitos internos, é como se as apenadas estivessem atestando a sua docilidade, o seu assujeitamento ao ARE; no entanto, ao agirem de forma contrária, buscam evitar a humilhação e romper com a relação de poder dominante, instaurando outra relação de poder avessa às determinaçôes do Aparelho. É aí que as apenadas conseguem se desvencilhar da repetição de padrôes comportamentais e criar uma ordem interna própria, que resiste às coerçôes penais.

Interessante observar na $\mathrm{SD}$ citada que existe uma ressalva importante referente ao funcionamento do Aparelho Repressor de Estado. A apenada menciona a ausência de controle total da polícia. Segundo ela, "a polícia manda... mas a polícia manda... paralelo... com as presas... eles mandam... mas a genti... as presa também mandam... é... embora eles não... 
eles não assumam isso né".

O emprego de conjunçóes adversativas possui um funcionamento discursivo peculiar. Destaca-se, portanto, a utilização do "mas" no excerto acima citado. Há duas afirmaçóes: "a polícia manda", de um lado, e "a polícia manda paralelo com as presas", de outro. As duas afirmaçóes só poderiam operar de forma não contraditória caso unidas por uma conjunção adversativa, pois não se poderia afirmar que a polícia manda e, também, que a polícia manda junto com as presas, pois geraria uma contradiçáo. Isso revela que há a mobilização de saberes oriundos de diferentes regióes do interdiscurso, os quais são colocados em conflito através da fala da apenada. Existe o reconhecimento, portanto, que o ARE deveria mandar na prisão de forma autônoma. Esse é o efeito de sentido que deve ser estabelecido a partir da superestrutura jurídico-política, ou seja, esse seria o único efeito de sentido permitido. Contudo, a apenada denuncia que, na práxis, não é assim que acontece. Existem outros efeitos de sentido que, apesar de não deverem e não poderem circular no espaço prisional (pois não estáo ligados à formação discursiva Jurídica) fazem parte destas condiçôes de produção. Aí a linguagem revela uma contradição inerente ao funcionamento da instituiçáo prisional. Apesar de a polícia achar que manda na prisão, existe um poder paralelo operando no interior das galerias, o qual foge do controle da polícia. É através da conjunção adversativa que se chega à contradição do funcionamento do Aparelho Repressor, pois ele também é atravessado pela ideologia, o que possibilita a materialização da contradição.

No interior das galerias, há um sistema paralelo, e é justamente por isso que a polícia náo é acionada quando ocorrem brigas entre as apenadas. Nesse tipo de situação, a solução é encontrada pelas próprias apenadas, internamente; elas mesmas decidem a forma como solucionar seus conflitos. Isso indica que há uma lei interna, uma lei que não obedece à Lei. Pode-se chegar à ideia de que, dentro das galerias, operam tanto a Lei do Aparelho de Estado quanto a lei do interior da prisão. Essa outra lei existe porque as apenadas a obedecem: a maioria das apenadas concorda que os conflitos internos devem ser resolvidos internamente, sem que se chame a Lei propriamente dita, representada pelas agentes penitenciárias. Há, destarte, as apenadas que se identificam com a Lei, vinculada à forma-sujeito de direito, bem como há as apenadas que se identificam com a lei interna da prisão, cujo funcionamento possui laços com a criminalidade. Caso não fosse assim, a maioria das apenadas entraria no consenso de que a polícia deveria ser acionada quando da existência de conflitos internos.

O controle, conforme afirma a apenada entrevistada, é paralelo, ou 
seja, eles andam juntos, sem que um exerça um controle maior do que o outro: "tem o controle pra fora do portáo ih o controle pra dentro do portão né". O controle paralelo do qual a apenada fala é um controle representado pelo portão que delimita onde as presas podem circular. Há, nessas condiçôes de produção, a possibilidade de resistir e de evitar a humilhação, apesar da tentativa de dessubjetivação dos sujeitos presos e, por conseguinte, de docilização dos corpos.

\section{Consideraçóes finais}

As consideraçóes tecidas acerca da relação entre a instituição prisional e os sujeitos que ocupam os cárceres levam ao reconhecimento da importância dos estudos de Althusser no que tange à organização da estrutura social e às relaçôes de dominância nela existentes. Com o suporte de autores do cenário filosófico, foi possível articular a teoria da Análise do Discurso pecheuxtiana às inquietaçốes da contemporaneidade, principalmente no que concerne ao movimento discursivo (ideológico e político, portanto) de dessubjetivação dos sujeitos. Esse processo visa à transformaçáo dos sujeitos em corpos individualizados, objetos de controle do Estado.

A partir do exposto por Foucault, Ansart e Haroche, parece que o sujeito preso não tem a completude (ilusória) do sujeito que está no exterior da penitenciária. Foucault $(2005 ; 2006)$ fala em vigília da alma; Ansart (2005) resgata a mecanicidade do corpo; Haroche (1992; 2005) traz a individualização, ou seja, a transformação do indivíduo em corpo. De acordo com esses elementos, será que a superestrutura permite a identificação em uma situação de enclausuramento pela prisão? Ao se trazer a reflexão althusseriana, pensamos que, por a prisão ser um aparelho ideológico e repressivo, a identificação não é permitida: deve existir obediência aos saberes da prisão, mas sem o sujeito se dar conta de que está obedecendo, por isso a necessidade de a cartilha ser distribuída. Contudo, observamos que, na prática, não é isso o que ocorre, pois as mulheres conseguem encontrar brechas para instalar um modo de funcionamento próprio ao interior das galerias, inacessível ao ARE, o que mostra, sim, a possibilidade de se identificar. 


\section{Referências}

ALTHUSSER, Louis. Aparelhos Ideológicos de Estado: Nota sobre os Aparelhos Ideológicos de Estado (AIE). Tradução Walter José Evangelista e Maria Laura Viveiros de Castro. 9. ed. Rio de Janeiro: Graal, 2003.

Sobre a reproduçáo. Tradução Guilherme João de Freitas Teixeira.

2. ed. Petrópolis: Vozes, 2008.

ANSART, Pierre. As humilhaçôes políticas. In: MARSON, Izabel; NAXARA, Márcia (Org.). Sobre a humilhação: sentimentos, gestos, palavras. Uberlândia: EDUFU, 2005.

CONSELHO NACIONAL DE JUSTIÇA (CNJ/Brasil). Cartilha da Mulher Encarceirada. Poder Judiciário, Brasília, DF, 2011.

FOUCAULT, Michel. Vigiar e punir: nascimento da prisão. Tradução Raquel Ramalhete. 30. ed. Petrópolis: Vozes, 2005.

Microfísica do poder. Tradução Roberto Machado. 22. ed. Rio de Janeiro: Graal, 2006.

HAROCHE, Claudine. Fazer dizer, querer dizer. Traduçáo Eni Orlandi. São Paulo: Hucitec, 1992.

Processos psicológicos e sociais de humilhação: o empobrecimento do espaço interior no individualismo contemporâneo. In: MARSON, Izabel; NAXARA, Márcia (Org.). Sobre a humilhaçáa: sentimentos, gestos, palavras. Uberlândia: EDUFU, 2005.

MARSON, Izabel; NAXARA, Márcia. Apresentação. In: MARSON, Izabel; NAXARA, Márcia (Org.). Sobre a humilhação: sentimentos, gestos, palavras. Uberlândia: EDUFU, 2005.

PÊCHEUX, Michel. Semântica e discurso: uma crítica à afirmação do óbvio. Tradução Eni Puccinelli Orlandi et al. 4. ed. Campinas: Editora da UNICAMP, 2009.

; FUCHS, Catherine. A propósito da Análise Automática do Discurso: Atualizaçôes e perspectivas (1975). In: GADET, Françoise; HAK, 
Tony. (Org.) Por uma análise automática do discurso: Uma introdução à obra de Michel Pêcheux. Traduçáo Bethania S. Mariani et al. 3. ed. Campinas: Unicamp, 1997.

Luciana Iost Vinhas - lucianavinhas@gmail.com

Artigo recebido em 12 de dezembro de 2014

e aceito em 16 de janeiro de 2015 . 